\title{
ピレンを骨格とする高性能蛍光色素並びにピレンの蛍光スイッチングを
} 利用した高感度蛍光センサ分子

藤本和久

\section{Highly Emissive Pyrene-based Fluorophores and Highly Sensitive Fluorescent Sensors Using Pyrene Emission Switching}

\author{
Kazuhisa Fujimoto \\ Graduate School of Pharmaceutical Sciences, University of Toyama, \\ Sugitani 2630, Toyama 930-0194, Japan
}

(Received May 31, 2010)

\begin{abstract}
In this review, I report highly emissive pyrene-based fluorophores and highly sensitive fluorescent sensors using pyrene emission switching. Alkynylpyrene derivatives show fruitful photophysical properties, as compared with pyrene itself: longer absorption and emission wavelengths and high fluorescence quantum yields in the presence of $\mathrm{O}_{2}$. Alkynylpyrene-based fluorescent probes allow the highly sensitive detection of biomolecules such as proteins. Additionally, a rotaxane-based fluorophore, consisting of an alkynylpyrene derivative and two cyclodextrins, is highly stable upon irradiation with a UV/vis illuminator. On the other hand, I and my colleagues have developed a variety of fluorescent sensors using pyrene emission switching. One of them is DNA probes in which two pyrenes are connected both at $3^{\prime}$ and $5^{\prime}$ ends of a single-stranded oligonucleotide. Emission switching occurs from excimer to monomer when the probes hybridized with target DNAs. The DNA probes met antibody structures to produce the following fluorescent sensors. The sensors consist of three functional regions, crown ether (or cyclodextrin), DNA, and pyrene as guest-binding, dimerizing, and sensing sites, respectively. These sensors can detect potassium cation, porphyrin, unsaturated fatty acid by pyrene monomer-excimer switching.
\end{abstract}

Key words_ - pyrene; alkynylpyrene; fluorophore; pyrene emission switching; fluorescent sensor

\section{1. はじめに}

代表的な蛍光色素の 1 つであるピレンは，希薄溶 液においてはモノマー発光を，濃厚溶液においては 二分子が近接し励起錯体を形成することでエキシ マー発光を示す. ${ }^{1)}$ この特徵的な性質を利用するこ とで，各種センサ分子の開発やDNA，タンパク 質，細胞膜といつた生体分子の位置・空間情報を得 るための研究が数多く行われてきた. ${ }^{2-5)}$ 本総説に おいては，筆者がこれまでに開発したピレンを骨格 とする優れた光物性を示す蛍光色素, 並びにピレン のエキシマー発光とモノマー発光のスイッチングを 利用した蛍光センサ分子に関する研究成果を紹介す る.

富山大学大学院医学薬学研究部（薬学）（９930-0194 富山市杉谷 2630)

e-mail: fujimoto@pha.u-toyama.ac.jp

本総説は, 平成 21 年度日本薬学会北陸支部学術奨励賞 の受賞を記念して記述したものである.
2. 高蛍光量子収率かつ酸素による消光を受け難 い蛍光色素：アルキニルピレン

ピレンは，化学修飾のし易さ，エキシマー発光を 示すといつた性質から，化学・生化学分野において 重用されてきた。しかしながら，励起波長（350 $\mathrm{nm}$ ）が比較的短波長，感度が悪い（蛍光量子収率 が低い), 酸素による消光が著しいといつた問題点 がある．筆者らによるピレンに関する光化学・超分 子化学の研究の過程で, $\left.{ }^{6}\right)$ 上記の欠点を克服するに は，種々のアルキニル基をピレン核に導入すればよ

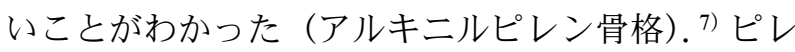
ン 1 並びに合成したアルキニルピレン誘導体 2-6 の 構造式とその吸収波長, モル吸光係数, 発光波長は Fig. 1 (a)の通りである。ピレン 1 の吸収波長，発 光波長に比べて，アルキニルピレン誘導体は吸収波 長において最大で $100 \mathrm{~nm}$ ，発光波長において 65 $\mathrm{nm}$ の長波長シフトを示した（励起波長の問題の解 決）。また高濃度溶液においては，ピレンの特徵的 
(a)

\begin{tabular}{|c|c|c|c|c|c|c|}
\hline $\begin{array}{c}\text { 1: } R^{1}=R^{2}=R^{3}=R^{4}=H \\
\mathbf{R}^{3} \curvearrowright R^{1} \text { 2: } R^{1}=C \equiv \operatorname{CSiMe}_{3}, R^{2}=R^{3}=R^{4}=H\end{array}$ & \multirow{2}{*}{$\begin{array}{l}\text { Pyrene } \\
\text { and } \\
\text { Alkynylpyrenes }\end{array}$} & \multicolumn{2}{|c|}{ Absorption ${ }^{3}$} & \multicolumn{2}{|c|}{$\begin{array}{c}\text { Emission }^{a} \\
\text { (Monomer) }^{-}\end{array}$} & \multirow{2}{*}{$\begin{array}{c}\begin{array}{c}\text { Emission } \\
\text { (Excimer) }\end{array} \\
\begin{array}{c}\text { Wavelength } \\
(\mathrm{nm})\end{array}\end{array}$} \\
\hline $\mathbf{R}^{3} \mathbf{R}^{1}$ 2: $\mathrm{R}^{1}=\mathrm{C} \equiv \mathrm{CSiMe}_{3}, \mathrm{R}^{2}=\mathrm{R}^{3}=\mathrm{R}^{4}=\mathrm{H}$ & & $\begin{array}{l}\text { Wavelength } \\
(\mathrm{nm})\end{array}$ & $\begin{array}{c}\varepsilon \\
\left(\times 10^{4}\right) \\
\left(\mathrm{mol}^{-1} \mathrm{dm}^{3} \mathrm{~cm}^{-1}\right)\end{array}$ & $\begin{array}{l}\text { Wavelength } \\
(\mathrm{nm})\end{array}$ & $\Phi_{\mathrm{f}}$ & \\
\hline & 1 & 334 & 4.63 & 373 & $0.32(0.019)^{b}$ & 475 \\
\hline 4: $R^{1}=R^{2}=R^{3}=C \equiv \operatorname{CSiMe}_{3}, R^{4}=H$ & 2 & 365 & 5.77 & 386 & 0.55 & 505 \\
\hline & 3 & 390 & 9.22 & 399 & 0.67 & 523 \\
\hline 5: $R^{1}=R^{2}=R^{3}=R^{4}=C \equiv C$ SiMe $_{3}$ & 4 & 413 & 10.0 & 421 & 0.80 & 545 \\
\hline 6: $R^{1}=C=C P h, R^{2}=R^{3}=R^{4}=H$ & 5 & 434 & 13.2 & 438 & $>0.99$ & 568 \\
\hline 6: $R^{\prime}=C=C P h, R^{2}=R^{3}=R^{4}$ & 6 & 382 & 4.47 & 391 & $0.78(0.56)^{b}$ & 509 \\
\hline
\end{tabular}

(b)

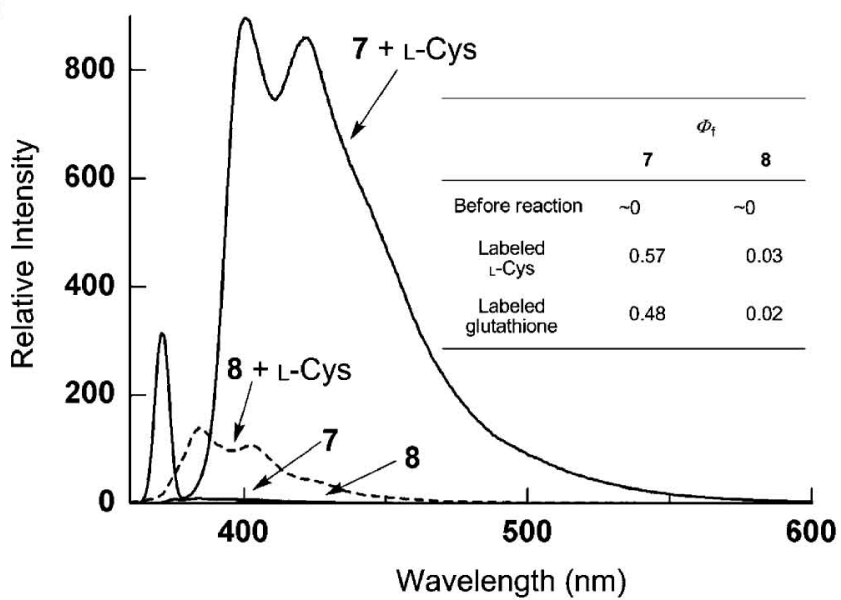

(c)

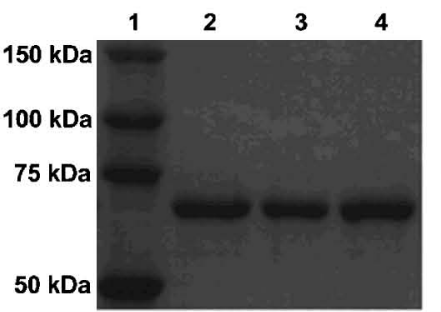

B
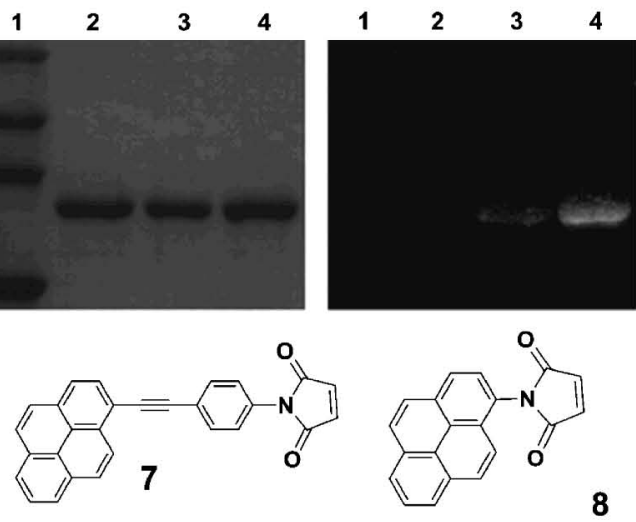

Fig. 1. Alkynylpyrenes

(a) Chemical structures and photophysical properties of pyrene $\mathbf{1}$ and alkynylpyrenes 2-6; ${ }^{a}$ all data were obtained in EtOH, ${ }^{b}$ the values in parentheses were obtained in the presence of $\mathrm{O}_{2}$. (b) Fluorescence spectra of 7 and $\mathbf{8}$ before and after the labeling reaction with $\mathrm{L}$-cysteine in $0.07 \mathrm{M}$ phosphate buffer solutions and the $\Phi_{\mathrm{f}}$ values of 7 and 8 before and after the labeling reactions. (c) SDS-PAGE photographs of BSA and its adducts. Photographs (A) and (B) were visualized by Coomassie blue staining and by irradiation with a UV/vis illuminator, respectively; lane 1: molecular weight markers, lane 2: BSA, lane 3: BSA labeled with 8, lane 4: BSA labeled with 7.

な性質であるエキシマー発光を示すこともわかっ た。酸素非存在下でのピレンの蛍光量子収率が 0.32 であるのに対して，同条件下でのアルキニル ピレンのそれは 0.5 以上であり，最も高いものにお いてはほぼ 1 であった(感度の問題の解決)。一方, ピレンの酸素存在下における蛍光量子収率は 0.019 まで下がるのに対して，アルキニルピレン誘導体の 場合，酸素の影響をほとんど受けないことがわかっ た。例えば $\mathbf{6}$ は酸素存在下でも高い蛍光量子収率 （0.56）を示した（酸素による消光の解決）。実際, 生体分子の蛍光検出においては, 酸素存在下での実 験を避けることができない。それゆえ，アルキニル ピレン骨格が示す酸素存在下での高い蛍光量子収率 は，高感度な生体分子プローブへの可能性を約束す る.この優れた光物性を生体分子の蛍光観察に応用 するために，アルキニルピレン骨格を化学修飾し， いくつかの蛍光ラベル化剂を開発した.アルキニル
ピレン誘導体 6 は，アルキニル基に連結したベンゼ ン環が存在するので，これを化学修飾することで多 彩な蛍光ラベル化剤へと誘導できる。一例として, $\mathbf{6}$ にマレイミド基を導入した蛍光ラベル化剂 7 を紹 介する $[$ Fig. 1(c)]。 マレイミド基はチオール基と 選択的に反応するので, タンパク中のシステイン残 基のラベル化に利用されている．7 の参照分子とし て，市販のピレンマレイミド 8 を用いた。まず，シ ステインやシステインを含むグルタチオンを 7 でラ ベル化し，ラベル化前後における蛍光特性を評価し た. ラベル化反応前において， 7 と 8 そのものの蛍 光スペクトルを確認することができず，蛍光量子収 率はともにほぼ 0 であった [Fig. 1(b)]。この消光 の原因はマレイミド基からの光誘起電子移動 (photoinduced electron transfer: PET) によるもの であることが確認された. ラベル化反応後, 8 でラ ベル化されたシステインやグルタチオンの蛍光量子 
収率は $0.03,0.02$,一方 7 でラベル化されたそれぞ れの蛍光量子収率は $0.57,0.48$ であった. 7 でラべ ル化されたものの蛍光量子収率は，8 の場合と比べ て約 20 倍であった。蛍光ラベル化剂 7 を用いるこ とで，蛍光のオン/オフスイッチングによりラベル 化反応の成否を判断することができ，かつ高感度で 生体分子を検出できることが判明した。Fig. 1 (c) は，複数のシステイン残基を含むタンパクであるウ シ血清アルブミン（BSA）を７と８でラベル化し た後のゲル電気泳動写真である．左側が Coomassie Blueで染色したもの，右側が光照射下において蛍 光を観察したものである. 右側の蛍光写真において, 7 でラベル化したレーン 4 においてのみはっきりと BSA 由来のバンドを確認することができた．以上 の結果より，アルキニルピレンを骨格とする 7 は, タンパク質のラベル化において有用な蛍光ラベル化 剤であることがわかった。

筆者らは，アルキニルピレン骨格の光材料として の可能性を調べるために，アルキニルピレンを骨格 とするオリゴマー分子や四置換アルキニルピレン誘 導体を合成し，その光物性を詳細に調べた。 ${ }^{8,9)}$ アル キニルピレン骨格をオリゴマー化させると， $\pi$ 電子 の共役が延びるにつれて，吸収・発光波長ともに大 きく長波長側にシフトすることが明らかとなった. 四置換アルキニルピレン誘導体においては，アセチ レンの末端にアニリン誘導体が連結されていると蛍 光ソルバトクロミズムを示すことがわかった。これ らの結果は，アルキニルピレン骨格の光材料として の可能性を示唆するものである.

最近，アルキニルピレン骨格をシクロデキストリ ンで包接しロタキサン型とした光褪色し難い青色発 光色素 9 を開発した (Fig. 2). ${ }^{10)}$ 蛍光色素に対して 長時間励起光を照射し続けると，徐々にその発光強 度が小さくなり褪色してしまう。光裉色は，励起光 を吸収し励起状態になった色素に活性酸素等が反応 することで非蛍光性分子に変わってしまう現象であ る。この光褪色を抑制することができれば，蛍光ラ ベル化した生体分子の挙動を長時間観測したり，一 分子蛍光観測に応用することができる.さらに材料 科学の分野において安定な発光を維持する色素は, 次世代の発光素材としての応用が期待される．例え ば，レーザーを光源とするディスプレイを開発する ためにはこのような色素の存在が必要不可欠であ

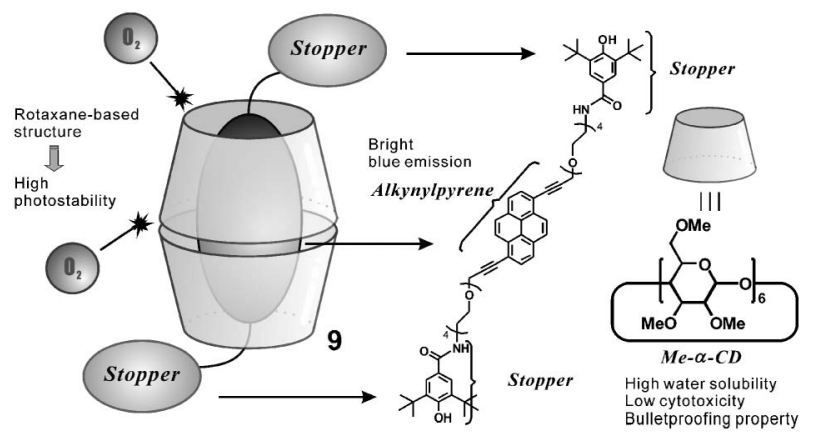

Fig. 2. A Rotaxane-based Fluorophore Consisting of an Alkynylpyrene and Two Cyclodextrins as Rod and Ring Moieties, Respectively

る、ロタキサン骨格のシクロデキストリン部位は, 発光部位であるアルキニルピレンを包接しバルクか ら隔離することで，活性酸素等の攻撃から守る，い わゆる防弾ガラス的役割を果たしている。また，紫 外光，可視光領域においてほとんど光を吸収しない ことから，包接する色素に対して電子的影響を与え る心配がない，合成したロタキサン型発光色素とシ クロデキストリン部位を持たないダンベル型参照分 子の各水溶液に対して，UVランプで長時間照射し たところ，ダンベル型参照分子はそのほとんどが非 蛍光性分子になってしまったのに対し，ロタキサン 型蛍光色素においてはほとんど変化がみられなかつ た．現在， $405 \mathrm{~nm}$ の青色ダイオードレーザーで励 起可能なロタキサン型発光色素を合成中である.

3. ピレンのエキシマー発光とモノマー発光のス イッチングを利用したセンサ分子

筆者らは，アルキニルピレン誘導体の開発と平行 してピレンのエキシマー発光とモノマー発光のスイ ッチングを利用した水溶性センサ分子の開発を行っ てきた。一番最初に開発したのが，DNA 検出プ ローブ分子である（Fig. 3). ${ }^{11 ）}$ 代表的な DNA 検出 プローブ分子であるモレキュラービーコン12)の骨格 として利用されているへアピンループ構造 DNA の 両末端に 2 枚のピレンを導入したもので, エキシ マー発光とモノマー発光のスイッチングによって ターゲット DNA 鎖を検出できる.ループ領域に対 する相補鎖が不在時にはステム構造が保持されてい るためエキシマー発光が，ループ領域と相補鎖が二 重鎖を形成しステム構造が解離することでモノマー 発光が検出される仕組みである. 開発したプローブ 分子は，その濃度が $10^{-8} \mathrm{M}$ という低濃度において 


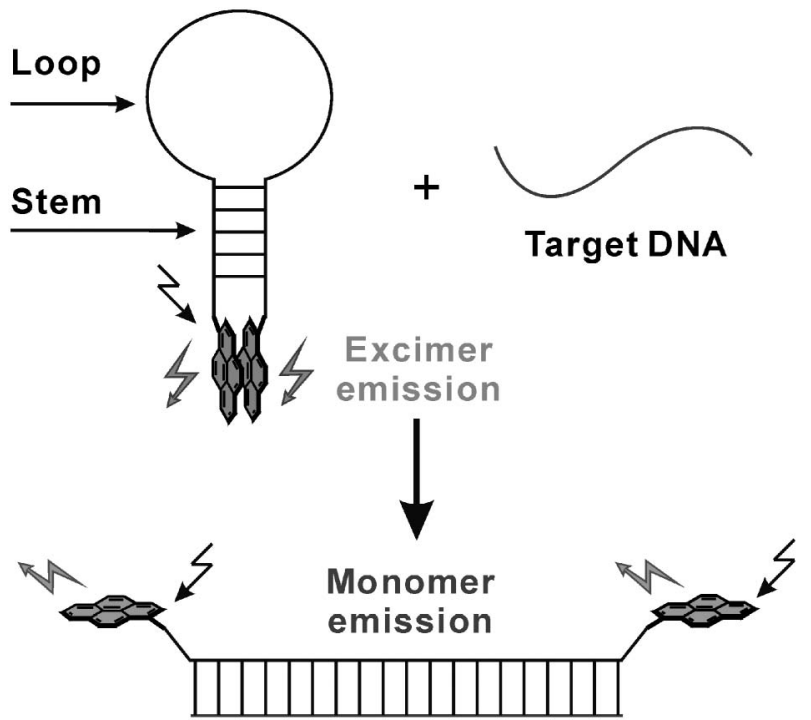

Fig. 3. Schematic Representation of DNA Probes Using Pyrene Excimer-monomer Switching

In the absence of target DNAs, the stem-close-shaped probes predominantly emit the excimer fluorescence. Upon hybridization with target DNAs, the probes undergo the dynamic conformational change to emit the monomer fluorescence.

もターゲット鎖を検出できる.

この DNA 検出プローブ分子の骨格と抗体の構造 を照らし合わせ開発に至ったのが以下に紹介するセ ンサ分子群である．先ほどの DNA 検出プローブ分 子の骨格からループ領域を除去し, 標的ゲスト分子 を捕捉できる部位を導入することで，ピレンの発光 スイッチングによってゲスト分子を検出できる抗体 様のセンサ分子を構築できると考えた [Fig. 4 (a)．ゲスト分子不在時には, DNA 部分が二重鎖 を形成しておらずピレンのモノマー発光が観測され る。ゲスト分子を加えるとゲスト分子認識部位との 間で会合体形成が生じ，それを駆動力として DNA 二重鎖形成が起こり, 結果ピレンエキシマー発光へ のスイッチングが起こる。この分子設計を基にまず 開発したのが，カリウムカチオンに対するセンサ分 子である [Fig. 4(b)].13) ゲスト分子認識部位とし て, カリウムカチオンと $1: 2$ の化学量論比でサン ドイッチ型の会合体を形成することが知られている ベンゾ 15-クラウン-5 エーテルを用いた。 カリウム カチオンを加えるとピレンのモノマー発光からエキ シマー発光へのスイッチングが観測された。 カリウ ムカチオンの添加によって DNA 二重鎖形成の融解 温度 $\left(T_{\mathrm{m}}\right)$ が上昇することから, カリウムカチオ ンとベンゾ 15-クラウン-5 エーテルとの会合が

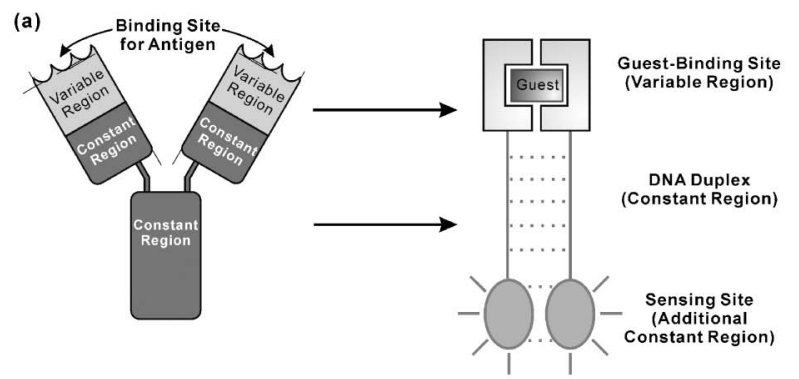

(b) Guest-Binding Moieties

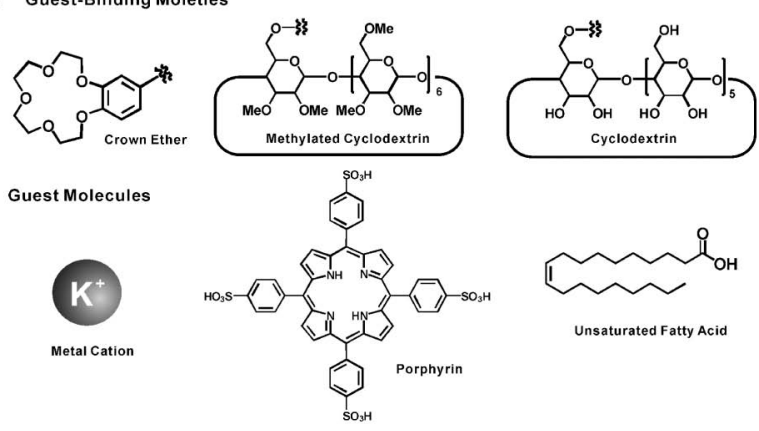

Fig. 4. DNA Duplex-based Fluorescent Sensors

(a) The structural motif of antibodies and the molecular design for duplex-based, fluorescent sensors working in water. (b) Chemiacal structures of the guest-binding moieties and their corresponding guest molecules.

DNA 二重鎖形成を促進していることが明らかとな った．また，このセンサ分子はナトリウムカチオン に対してカリウムカチオンを選択的に検出すること もわかつた. この分子設計の一般性を示すために, ゲスト分子認識部位としてメチル化シクロデキスト リンを導入したセンサ分子を合成した $[$ Fig. 4 (b) ] . ${ }^{14)}$ メチル化 $\beta$-シクロデキストリンは， $2: 1$ の錯形成比でポルフィリン誘導体と強く会合するこ とが知られている.このセンサ分子の水溶液にポル フィリン誘導体を加えると, カリウムカチオンセン サの時と同様にピレンの発光スイッチング，並びに $T_{\mathrm{m}}$ の上昇が観測された.

最近，センサ分子の合成を簡略化するためにクリ ック反応を利用して $\alpha$-, 並びに $\beta$-シクロデキスト リンを導入したセンサ分子を合成した [Fig. 4 (b) ] . 15) シクロデキストリンのアジ化物と DNA 上 に導入したアセチレンとの間でクリック反応を行 う。ゲスト分子としてステアリン酸・オレイン酸・ エライジン酸・アラキドン酸といつた各種脂肪酸を 用いた. $\beta$-シクロデキストリンで修飾したセンサ分 子において，ステアリン酸を除く不飽和脂肪酸に対 して蛍光のスイッチングが観測された．空孔サイズ の小さい $\alpha$-シクロデキストリンを導入したセンサ 
分子を用いて，これらの不飽和脂肪酸を加えたとこ ろオレイン酸において最も大きな蛍光スイッチング が観測された。この選択性は，空孔サイズが小さく なったことで不飽和脂肪酸の二重結合の数や立体配 置の違いが会合に反映され生じたものであると考え られる。この結果は，不飽和脂肪酸を蛍光で選択的 に検出した初めての例である。筆者らが考案した分 子設計を用いることで，抗体のような多様性を持っ た DNA 二重鎖を骨格とする蛍光センサ分子群の構 築が可能となる。

\section{4. おわりに}

本総説で紹介した研究成果は，ピレンという発光 色素の新たな可能性を示す．特に，ロタキサン型の 発光色素はこれまでの発光素材にない特徵を有して いるので，生体分子の一分子蛍光観測への利用や次 世代ディスプレイ開発につながる発光素材への応用 が期待される。

謝辞 これら研究成果は，筆者が在籍する富山 大学大学院医学薬学研究部 (薬学) 薬化学研究室 (井上将彦教授主宰) の多大なサポートのもとに得 られたものである.アルキニルピレン誘導体の蛍光 量子収率測定は, 大阪府立大学大学院工学研究科の 水野一彦教授と金沢大学理工学域物質化学類の前多 肇准教授の協力で行われた。最後に井上将彦教授を 始め協力を賜った方々に感謝する.

\section{REFERENCES}

1) Winnik F. M., Chem. Rev., 93, 587-614 (1993).

2) Saito Y., Okamoto A., Saito I., Bioindustry, 23, 56-62 (2006).
3) Zama M., Bryan P. N., Harrington R. E., Olins A. L., Olins D. E., Cold Spring Harbor Symp. Quant. Biol., 42, 31-41 (1978).

4) Lehrer S. S., "Subcellular Biochemistry, Vol. 24, Proteins: Structure, Function, and Engineering," eds. by Biswas B. B., Roy S., Plenum Press, New York, 1995, pp. 115-132.

5) Wieb van der Meew B., "Subcellular Biochemistry, Vol. 13, Fluorescence Studies on Biological Membranes," ed. by Hilderson H. J., Plenum Press, New York, 1988, pp. 1-53.

6) Inouye M., Fujimoto K., Furusyo M., Nakazumi H., J. Am. Chem. Soc., 121, 14521458 (1999).

7) Maeda H., Maeda T., Mizuno K., Fujimoto K., Shimizu H., Inouye M., Chem. Eur. J., 12, 824-831 (2006).

8) Shimizu H., Fujimoto K., Furusyo M., Maeda H., Nanai Y., Mizuno K., Inouye M., J. Org. Chem., 72, 1530-1533 (2007).

9) Fujimoto K., Shimizu H., Furusyo M., Akiyama S., Ishida M., Furukawa U., Yokoo T., Inouye M., Tetrahedron, 65, 9357-9361 (2009)

10) Fujimoto K., Yonenaga Y., Inouye M., unpublished data.

11) Fujimoto K., Shimizu H., Inouye M., J. Org. Chem., 69, 3271-3275 (2004).

12) Tyagi S., Kramer F. R., Nat. Biotechnol., 14, 303-308 (1996).

13) Fujimoto K., Muto Y., Inouye M., Chem. Commun., 4780-4782 (2005).

14) Fujimoto K., Muto Y., Inouye M., Bioconjugate Chem., 19, 1132-1134 (2008) .

15) Fujimoto K., Yamada S., Inouye M., Chem. Commun., 7164-7166 (2009). 